\title{
PERAN BISNIS PERTANIAN DALAM PEREKONOMIAN INDONESIA
}

\author{
Ach Rofiqi, Mahrus Ali, Siwidyah Desi Lastianti, Yeni Ika Pratiwi \\ Universitas Merdeka Surabaya
}

\begin{abstract}
ABSTRAK
Bisnis pertanian merupakan bisnis perkebunan, kehutanan, peternakan, perikanan. Potensi bisnis pertanian terhadap perekonomian Indonesia dapat dilihat dari potensi keanekaragaman hayati yang begitu banyak dan tersebar di berbagai daerah di Indonesia. Potensi perikanan yang melimpah karena kondisi Indonesia adalah Negara kepulauan. Selain itu Indonesia juga mempunyai potensi lahan yang luas dan mampu menyerap tenaga kerja dalam peningkatan perekonomian masyarakat sehingga mampu berkontribusi dalam peningkatan pendapatan nasional.
\end{abstract}

Kata Kunci: Bisnis Pertanian, Ekonomi Pertanian dan Peran Pertanian.

\section{PENDAHULUAN}

Menurut Suratiyah (2006), pertanian sebagai kegiatan manusia dalam membuka lahan dan menanaminya dengan berbagai jenis tanaman yang termasuk tanaman semusim maupun tanaman tahunan dan tanaman pangan maupun tanaman non-pangan serta digunakan untuk memelihara ternak maupun ikan. Dengan berbagai tujuan dan alasan mengapa lahan dibuka dan diusahakan oleh manusia. Apabila pertanian dianggap sebagai sumber kehidupan lapangan kerja. Pertanian dapat mengandung dua arti yaitu (1) dalam arti sempit atau seharihari diartikan sebagai kegiatan cocok tanam dan (2) dalam arti luas diartikan sebagai kegiatan yang menyangkut proses produksi menghasilkan bahan-bahan kebutuhan manusia yang dapat berasal dari tumbuhan maupun hewan yang disertai dengan usaha untuk memperbaharui, memperbanyak (reproduksi) dan mempertimbangkan faktor ekonomis (Lestari, 2017). Pertanian tersebut merupakan kegiatan yang dilakukan oleh manusia pada suatu lahan tertentu, dalam hubungan tertentu antara manusia dengan lahannya yang disertai berbagai pertimbangan tertentu pula.

Bicara masalah bisnis memang sedang dalam gencar-gencarnya massa sekarang ini. Bagaimana tidak, akhir-akhir ini mulai banyak orang yang mencoba keberuntunganya dalam berbisnis. Alhasil, berbisnis dari tingkatan rendah ke tingkatan tinggi dalam berbagai bidang mulai marak di banyak tempat. Tak luput bidang pertanian yang idealisnya sangat potensial 
di negeri ini (LASTIANTI, 2015). Akhirnya bisnis bidang pertanian mulai banyak diminati kalangan masyarakat luas.

\section{Pertanian dan Usahatani}

\section{Pertanian}

Menurut Rahim (2007), pertanian yaitu merupakan kegiatan dalam usaha mengembangkan (reproduksi) tumbuhan dan hewan supaya tumbuh lebih baik untuk memenuhi kebutuhan manusia, misalnya bercocok tanam, beternak, dan melaut. Pertanian juga sebagai jenis usaha atau kegiatan ekonomi berupa penanaman tanaman atau usahatani (pangan, holtikultura, perkebunan, dan kehutanan), peternakan (beternak) dan perikanan (budidaya dan menangkap).

\section{Usahatani}

Usahatani menurut Djamali (2000), adalah kesatuan organisasi antara faktor produksi berupa lahan, tenaga kerja, modal dan manajemen yang bertujuan untuk memproduksi komoditas pertanian. Usahatani sendiri pada dasarnya merupakan bentuk interaksi antara manusia dan alam di mana terjadi saling mempengaruhi antara manusia dan alam sekitarnya. Dan menurut Suratiyah, (2006), usahatani adalah ilmu yang mempelajari bagaimana seorang mengusahakan dan mengkoodinir faktor-faktor produksi berupa lahan dan alam sekitarnya seebagai modal sehingga memberikan manfaat sebaik-baiknya. Sebagai ilmu pengetahuan, ilmu usahatani merupakan ilmu yang mempelajari cara-cara petani menentukan, mengorganisasikan, dan mengkoordinasikan pengunaan faktor-faktor produksi seefektif dan seefisien mungkin sehingga usaha tersebut memberikan pendapatan semaksimal mungkin. Ada banyak definisi ilmu usahatani yang diberikan.

Menurut Mubyarto (1989), usahatani adalah himpunan dari sumber- sumber alam yang terdapat di tempat itu yang diperlukan untuk produksi pertanian seperti tubuh tanah dan air, perbaikan - perbaikan yang telah dilakukan atas tanah itu, sinar matahari, bangunan bangunan yang didirikan diatas tanah dan sebagainya. Soekartawi (1995), mengungkapkan bahwa ilmu usahatani adalah ilmu yang mempelajari bagaimana seseorang mengalokasikan sumber daya yang ada secara efektif dan efisien untuk memperoleh keuntungan yang tinggi pada waktu tertentu. Lebih lanjut menurut Vink (1984), mengungkapkan ilmu usahatani merupakan ilmu yang mempelajari norma-norma yang digunakan untuk mengatur usahatani agar memperoleh pendapatan yang setinggi-tingginya. Ilmu yang mempelajari segala sesuatu yang berhubungan dengan kegiatan manusia dalam melakukan pertanian disebut Ilmu Usahatani. 
Prawirokusumo (1990), mengungkapkan ilmu usahatani merupakan ilmu terapan yang membahas atau mempelajari bagaimana membuat atau menggunakan sumberdaya secara efisien pada suatu usaha pertanian, peternakan, atau perikanan.

Selain itu, juga dapat diartikan sebagai ilmu yang mempelajari bagaimana membuat dan melaksanakan keputusan pada usaha pertanian, peternakan, atau perikanan untuk mencapai tujuan yang telah disepakati oleh petani/ peternak tersebut.

\section{Peran Subsektor Perkebunan dalam Perekonomian Indonesia}

Menurut Susila (2004), subsektor perkebunan merupakan salah satu subsektor yang mengalami pertumbuhan paling konsisten, baik ditinjau dari areal maupun produksi. Secara keseluruhan, areal perkebunan meningkat dengan laju $2.6 \%$ per tahun pada periode tahun 2000-2003, dengan total areal pada tahun 2003 mencapai 16.3 juta. Dari beberapa komoditas perkebunan yang penting di Indonesia (karet, kelapa sawit, kelapa, kopi, kakao, teh, dan tebu), kelapa sawit, karet dan kakao tumbuh lebih pesat dibandingkan dengan tanaman perkebunan lainnya dengan laju pertumbuhan diatas $5 \%$ per tahun.

Pertumbuhan yang pesat dari ketiga komoditas tersebut pada umumnya berkaitan dengan tingkat keuntungan penguasahaan komoditas tersebut relatif lebih baik dan juga kebijakan pemerintah untuk mendorong perluasan areal komoditas tersebut. Indonesia mempunyai potensi untuk menjadi produsen utama kakao dunia, apabila berbagai permasalahan utama yang dihadapi perkebunan kakao dapat diatasi dan agribisnis kakao dikembangkan dan dikelola secara baik.Indonesia masih memiliki lahan potensial yang cukup besar untuk pengembangan kakao, yaitu lebih dari 6,2 juta ha terutama di Papua, Kalimantan Timur, Sulawesi Tengah,Sulawesi Tenggara, dan Maluku (Pusat Penelitian dan Pengembangan Tanah dan Agroklimat, 2005).

Disisi lain situasi perkakaoan dunia beberapa tahun terakhir sering mengalami defisit, sehingga harga kakao dunia stabil pada tingkat yang tinggi (Roesli, Heri, \& Rahayu, 2017). Kondisi ini merupakan suatu peluang yang baik untuk segera dimanfaatkan. Upaya peningkatan produksi kakao mempunyai arti yang strategis karena pasar ekspor biji kakao Indonesia masih sangat terbuka dan pasar domestik masih belum tergarap. Menurut Goenadi (2005), dengan kondisi harga kakao dunia yang relatif stabil dan cukup tinggi maka perluasan areal perkebunan kakao Indonesia diperkirakan akan terus berlanjut dan hal ini perlu mendapat dukungan agar kebun yang berhasil dibangun dapat memberikan produktivitas yang tinggi. Pada tahun 2025, sasaran untuk menjadi produsen utama kakao dunia dapat menjadi kenyataan karena pada tahun tersebut total areal perkebunan kakao Indonesia diperkirakan mencapai 1,35 juta ha dan mampu menghasilkan 1,3 juta ton/tahun biji kakao. 
Wayang (2004), mengungkapkan peran strategis lain dari subsektor perkebunan dalam isu global yang perlu mendapat perhatian adalah kontribusinya dalam ketahanan pangan. Minyak goreng dan gula merupakan produk perkebunan yang mempunyai peran penting dalam memelihara ketahanan pangan. Negara-negara maju seperti Amerika, Jepang, Eropa, berusaha memaksimalkan tingkat produksi pangannya dalam upaya mencapai ketahanan pangan. Seperti diketahui, ketahanan pangan merupakan salah satu syarat penting dalam ketahanan nasional(Ali, 2015).

Subsektor perkebunan memiliki posisi yang tak bisa diremehkan. Dengan orientasi pasar ekspor, perkebunan merupakan salah satu subsektor andalan dalam menyumbang devisa. Produk karet, kopi, kakao, teh dan minyak sawit adalah produkproduk dimana lebih dari $50 \%$ dari total produksi adalah untuk ekspor. Hingga tahun 2004, subsektor perkebunan secara konsisten menyumbang devisa dengan dengan rata-rata nilai ekspor produk primernya mencapai US\$ 4 miliar per tahun. Nilai tersebut belum termasuk nilai ekspor produk olahan perkebunan, karena ekspor olahan perkebunan dimasukkan pada sektor perindustrian Arham, (2009). Sukanda (2003), mengungkapkan usaha sektor perkebunan memegang peranan strategis dalam mendukung perekonomian Indonesia melalui kegiatan ekspor hasil primer perkebunan yang memberikan kontribusi kepada Negara berupa pemasukan pupuk dan dividen, dan secara langsung maupun tidak langsung keberadaan perusahaan, perkebunan besar turut serta dalam upaya-upaya pengembangan wilayah yang secara nyata berdampak terhadap kemajuan masyarakat baik secara ekonomi maupun sosial.

Susila (2004), mengungkapkan subsektor perkebunan juga berperan penting dalam hal isu lingkungan yang merupakan isu global yang secara konsisten gaungnya semakin menguat. Pengembangan komoditas perkebunan diareal yang marginal merupakan wujud kontribusi subsektor perkebunan dalam memelihara lingkungan/ konservasi. Sebagai contoh. pengembangan tanaman teh di daerah pegunungan dengan kemiringan yang tajam dengan kondisi lahan yang kritis, berperan penting dalam konservasi lingkungan. Pengembangan komoditas karet di lahan kering dan kritis juga memberi kontribusi nyata dalam memelihara bahkan memperbaiki lingkungan, pengembangan komoditas karet dalam bentuk agroforestri serta pemanfaatan kayu karet sebagai pengganti kayu dari hutan primer merupakan kontribusi lain perkebunan karet dalam konservasi lingkungan. Pengembangan komoditas kelapa sawit di lahan rawa juga merupakan wujud kontribusi subsektor perkebunan dalam memelihara lingkungan. Selanjutnya, pemanfaatan CPO sebagai bahan baku biodiesel juga merupakan bentuk lain dari pengembangan perkebunan dengan pendekatan pembangunan berkelanjutan. 
Pada masa mendatang. kontribusi ini akan semakin strategis ketika cadangan minyak bumi yang dimiliki semakin menipis serta harga minyak yang mulai meningkat.

Menurut Goenadi (2005), perluasan areal pengembangan kakao saat ini ada kecenderungan terus berlanjut dengan laju perluasannya rata-rata tumbuh $2 \%-2,5 \% /$ tahun, akan tetapi ada masalah serangan penggerek buah kakao (PBK) yang cendrung terus meluas. Oleh karena itu perlu upaya rehabilitasi untuk meningkatkan potensi kebun yang sudah ada melalui perbaikan bahan tanaman dengan teknologi sambung samping atau penyulaman dengan bibit unggul. Tetapi apabila upaya rehabilitasi tidak memungkinkan, maka perbaikan potensi kebun dapat dilakukan melalui peremajaan. Kedua kegiatan ini bertujuan untuk meningkatkan produktivitas kebun-kebun kakao yang sudah dibangun petani. Dengan melakukan berbagai upaya perbaikan tersebut, maka perluasan areal perkebunan kakao diharapkan terus berlanjut. Pada priode 2005- 2010, areal perkebunan kakao diperkirakan masih tumbuh dengan laju 2,5\% - $3 \%$ /tahun sehingga total areal perkebunan kakao diharapkan menjadi 1.105 .430 ha dengan total produksi 730.000 ton.

Susila (2004), mengungkapkan bahwa peran subsektor perkebunan yang semakin strategis, pengembangan subsektor perkebunan masih mengalami beberapa kendala dan hambatan yang perlu segera diatasi. Pertama, kebanyakan tanaman perkebunan yang ada adalah tanaman yang sudah tua sehingga produktivitas rendah. Di sisi lain, upaya untung melakukan replanting masih mengalami masalah, terutama dari sisi pendanaan. Kedua pengembangan subsektor perkebunan juga masih menghadapi masalah yang berkaitan dengan HGU, baik itu mencakup luasan maupun masa berlaku HGU yang dinilai masih teralu pendek untuk perkebunan dengan siklus produksi sekitar 30 tahun. Ketiga, masih adanya konflik tanah dan sosial antara perusahaan perkebunan dengan masyarakat sekitar merupakan masalah yang juga perlu segera diatasi. Keempat, pengenaan PPN pada produk perkebunan juga dinilai sebagai salah satu hambatan dalam pengembangan subsektor perkebunan. Kelima, belum adanya semacam cetak biru pengembangan subsektor perkebunan juga dinilai sebagai salah satu hambatan dalam pengembangan bisnis perkebunan.

\section{Peran Perkebunan Kakao Bagi Perekonomian Nasional}

Peran komoditas strategis nasional pada subsektor perkebunan, diantaranya sawit, karet, kakao dan tebu memberikan sumbangsih yang sangat besar dalam perekonomian nasional Indonesia. Sub sektor perkebunan telah menyumbangkan penerimaan ekspor yang selalu meningkat setiap tahunnya, yaitu pada tahun 2007 sebesar 19.948.923 ribu US\$, tahun 2008 sebesar 27.369.363 ribu US\$ dan tahun 2009 (sampai dengan bulan September) sebesar 21.581.670 ribu US\$. Sumbangsih tersebut dapat menjadi lebih optimum dengan 
memperkuat penciptaan nilai tambah dengan mengangkat dan memfasilitasi berbagai pemikiran dan inisiatif yang telah dikembangkan Pemerintah Pusat dan Pemerintah Daerah, pelaku dunia usaha dan investasi serta masyarakat pekebun pada sub sektor perkebunan dan sektor terkait lainnya, akademisi dan para peneliti, organisasi masyarakat sipil, masyarakat umum dan lembaga internasional bilateral dan multilateral. Berbagai pemikiran dan inisiatif tersebut menjadi un

sur-unsur yang merangsang penemuan dan pengembangan ilmu pengetahuan, teknologi dan manajemen yang akan memperkuat daya saing bagi komoditas strategis nasional pada sub sektor perkebunan. Negara yang bertujuan mencerdaskan dan meningkatkan kesejahteraan rakyat serta mewujudkan cita-cita Bangsa dalam segala dimensinya melalui pelestarian dan pengembangan komoditas strategis nasional pada sub sektor perkebunan. Mengungkapkan (Badan Penelitian dan Pengembangan Pertanian, 2011), beberapa kebijakan pemerintah yang sangat dibutuhkan dalam pengembangan agribisnis kakao 5 sampai 20 tahun ke depan antara lain: Penghapusan PPN dan berbagai pungutan, aktif mengatasi hambatan ekspor dan melakukan lobi untuk menghapuskan potangan harga, mendukung upaya pengendalian hama PBK dan perbaikan mutu produksi serta menyediakan fasilitas pendukungnya secara memadai.

Menurut Goenadi (2004), dari segi nilai absolut berdasarkan harga yang berlaku. PDB perkebunan terus meningkat dari sekitar Rp 33.7 triliun pada tahun 2000 menjadi sekitar Rp 47.0 triliun pada tahun 2003, atau meningkat dengan laju sekitar $11.7 \%$ per tahun. Dengan peningkatan tersebut, kontribusi PDB subsektor perkebunan terhadap PDB sektor pertanian adalah sekitar $16 \%$. Terhadap PDB secara nasional tanpa migas, kontribusi subsektor perkebunan adalah sekitar $2.9 \%$ atau sekitar 2.6\% PDB total. Jika menggunakan PDB dengan harga konstan tahun 1993, pangsa subsektor perkebunan terhadap PDB sektor pertanian adalah $17.6 \%$, sedangkan terhadap PDB nonmigas dan PDB nasional masingmasing adalah $3.0 \%$ dan $2.8 \%$.

Perkebunan kakao di Indonesia mengalami perkembangan pesat dalam kurun waktu 25 tahun terakhir dan pada tahun 2004 areal perkebunan kakao Indonesia tercatat seluas 992.191 ha. Perkebunan kakao tersebut sebagian besar $(89,59 \%)$ dikelola oleh rakyat dan selebihnya 5,04\% dikelola perkebunan besar negara serta 5,37\% perkebunan besar swasta. Jenis tanaman kakao yang diusahakan sebagian besar adalah jenis kakao lindak dengan sentra produksi utama adalah Sulawesi Selatan, Sulawesi Tenggara dan Sulawesi Tengah. Disamping itu juga diusahakan jenis kakao mulia oleh perkebunan besar negara di Jawa Timur dan Jawa Tengah. Untuk mencapai sasaran produksi tersebut diperlukan investasi 
sebesar Rp 16,72 triliun dan dukungan berbagai kebijakan untuk menciptakan iklim usaha yang kondusif (Badan Penelitian dan Pengembangan Pertanian, 2011).

Dana investasi tersebut sebagian besar bersumber dari masyarakat karena pengembangan kakao selama ini umumnya dilakukan secara swadaya oleh petani. Dana pemerintah diharapkan dapat berperan dalam memberikan pelayanan yang baik dan dukungan fasilitas yang tidak bisa ditanggulangi petani seperti biaya penyuluhan dan bimbingan, pembangunan sarana dan prasaran jalan dan telekomunikasi, dukungan gerakan pengendalian hama PBK secara nasional, dukungan untuk kegiatan penelitian dan pengembangan industri hilir (Badan Penelitian dan Pengembangan Pertanian, 2011).

\section{Karakteristik Usahatani}

Aulia (2010), membagi karakteristik usahatani menjadi 2 macam yaitu Karakteristik Sosial dan Karakteristik Ekonomi

\section{Karakteristik Sosial}

Faktor sosial terdiri dari umur, pendidikan, pengalaman berusahatani, jumlah tanggungan petani.

a. Umur.

Menurut Soekartawi (2003), rata rata petani Indonesia yang cenderung tua dan sangat berpengaruh pada produktivitas sektor pertanian Indonesia Petani berusia tua biasanya cenderung sangat konservatif (memelihara) menyikapi perubahan terhadap inovasi teknologi. Berbeda halnya dengan petani yang berusia muda.

Umur petani adalah salah satu faktor yang berkaitan erat dengan kemampuan kerja dalam melaksanakan kegiatan usahatani, umur dapat dijadikan sebagai tolak ukur dalam melihat aktivitas seseorang dalam bekerja bilamana dengan kondisi umur yang masih produktif maka kemungkinan besar seseorang dapat bekerja dengan baik dan maksimal (Hasyim,2003).

\section{b. Pendidikan}

Soekartawi (2003) mengemukakan bahwa banyaknya atau lamanya sekolah/pendidikan yang diterima seseorang akan berpengaruh terhadap kecakapannya dalam pekerjaan tertentu. Sudah tentu kecakapan tersebut akan mengakibatkan kemampuan yang lebih besar dalam menghasilkan pendapatan bagi rumah tangga.

Menurut Hasyim (2003), tingkat pendidikan formal yang dimiliki petani akan menunjukkan tingkat pengetahuan serta wawasan yang luas untuk petani menerapkan apa yang diperolehnya untuk peningkatan usahataninya. Mengenai tingkat pendidikan petani, dimana mereka yang berpendidikan tinggi relatif lebih cepat dalam melaksanakan adopsi 
inovasi. Tingkat pendidikan manusia pada umumnya menunjukkan daya kreatifitas manusia dalam berfikir dan bertindak. Pendidikan rendah mengakibatkan kurangnya pengetahuan dalam memanfaatkan sumber daya alam yang tersedia (Kartasapoetra,1987).

c.Lamanya berusahatani.

Menurut Soekartawi (2003), pengalaman seseorang dalam berusahatani berpengaruh dalam menerima inovasi dari luar. Petani yang sudah lama bertani akan lebih mudah menerapkan inovasi dari pada petani pemula atau petani baru. Petani yang sudah lama berusahatani akan lebih mudah menerapkan anjuran penyuluhan dimikian pula dengan penerapan teknologi.

Lamanya berusahatani untuk setiap orang berbeda beda, oleh karena itu lamanya berusahatani dapat dijadikan bahan pertimbangan agar tidak melakukan kesalahan yang sama sehingga dapat melakukan hal hal yang baik untuk waktu waktu berikutnya (Hasyim, 2003). Petani yang berusia lanjut sekitar 50 tahun ke atas, biasanya fanatik terhadap tradisi dan sulit untuk diberikan pengertian yang dapat mengubah cara berfikir, cara kerja, dan cara hidupnya. Mereka ini bersikap apatis terhadap adanya teknologi baru dan inovasi, semakin muda umur petani, maka semakin tinggi semangatnya mengetahui hal baru, sehingga dengan demikian mereka berusaha untuk cepat melakukan adopsi walaupun sebenarnya mereka masih belum berpengalaman soal adopsi tersebut (Kartasapoetra, 1987).

d.Jumlah tanggungan.

Menurut Hasyim (2003), jumlah tanggungan keluarga adalah salah satu faktor yang perlu diperhatikan dalam menentukan pendapatan dalam memenuhi kebutuhannya. Banyaknya jumlah tanggungan keluarga akan mendorong petani untuk melakukan banyak aktivitas terutama dalam mencari dan menambah pendapatan keluarganya. Semakin banyak anggota keluarga akan semakin besar pula beban hidup yang akan ditanggung atau harus dipenuhi. Jumlah anggota keluarga akan mempengaruhi keputusan petani dalam berusahatani (Soekartawi, 2003).

\section{Karakteristik Ekonomi}

Karakteristik ekonomi yang berhububungan dengan Usahatani kakao adalah Luas kebun, pohon menghasilkan, pohon belum menghasilkan, pohon tidak menghasilkan, biaya usahatani, produksi usahatani, pendapatan usahatani.

a. Luas Kebun

Luas perkebunan kakao di Indonesia terus meningkat sepanjang 5 tahun terakhir. Pada tahun 2007 luas perkebunan kakao di Indonesia mencapai 1379279 Ha. Luas perkebunan ini mengalami pertumbuhan sebesar 6.8 persen menjadi 1473259 Ha. Luas 
perkebunan kakao kembali bertambah menjadi 1592982 Ha atau tumbuh 8.1 persen pada tahun berikutnya. Secara rata-rata pertumbuhan luas perkebunan kakao di Indonesia dari tahun 2006 hingga tahun 2009 adalah 8.1 persen. Yakni perkebunan yang dimiliki masyarakat. Kepemilikan perkebunan ini rata-rata per petani sangat kecil yakni 1 Ha per petani. Luas perkebunan kakao yang dimiliki masyarakat sekitar 92,7 persen dari luas total perkebunan kakao di Indonesia pada tahun 2009 yang mencapai 1.592.982 Ha (Indonesia Comercial Newsletter (ICN), 2010).

b. Tanaman yang Menghasilkan

Tanaman yang berproduksi pada tanaman perkebunan terutaman kakao memberikan hasil yang maksimal pada petani dalam melakukan usahatani kakao. Pada satu daerah yang memiliki mayoritas petani kakao dibutuhkan dukungan iklim yang baik dan perawatan yang memungkinkan tanaman kakao dapat berproduksi. Penyiraman tanaman kakao yangtumbuh dengan kondisi tanah yang baik dan memiliki pohon pelindung tidak memerlukan banyak air. Air yang berlebihan akan menyebabkan kondisi tanah menjadi sangat lembab. Penyiraman dilakukan pada tanaman muda, terutama tanaman yang tidak memiliki pohon pelindung.Pepohonansangat sensitif terhadap kadar air. Curah hujan yangdibutuhkan harus tinggi dan terdistribusi dengan baik sepanjangtahun. Tingkat curah hujan yang baik per tahun berkisar antara $1500 \mathrm{~mm}$ - $2500 \mathrm{~mm}$. Curah hujan saat musim kemarau sebaiknya lebih kurang dari $100 \mathrm{~mm}$ per bulan dan tidak lebih dari tiga bulan (Depperin, 2007).

c. Tanaman yang Belum Menghasilkan

Pada tanaman kakao memiliki jenjang waktu dalam melakukan produksi, pada saat penanaman waktu yang diperlukan oleh tanaman kakao dalam melakukan produksi tergantung pada tehnik atau cara bagaimana meberlakukan tanaman kakao. Tanaman kakao yang ditanam melalui sambung samping memerlukan waktu sedikit dalam melakukan produksi dibandingkan dengan penanaman yang tampa melakukan sambung samping.Pemberantasan hama dilakukan dengan penyem protan pestisida dalam dua tahap. Pertama bertujuan untuk mencegah sebelum diketahui ada hama yang menyerang. Kadar dan jenis pestisida disesuaikan. Tahap yang kedua adalah usaha pemberantasan hama, dimana jenis dan kadar pestisida yang digunakan ditingkatkan (Depperin, 2007).

d. Tanaman yang Tidak Menghasilkan

Tanaman kakao yang sudah tidak berproduksi dikarenakan banyak faktor antara lain, kurangnya pengeahuan petani dalam berusahatani kakao, faktor lingkungan sehingga dapat menimbulkan hama pada tanaman dan kondisi lahan yang tidak sesuai.Hama yang sering menyerang tanaman kakao antara lain belalang ( Valanga Nigricornis), ulat jengkal 
(Hypsidratalaka Walker), kutu putih (Planoccos lilaci), penghisap buah (Helopeltis sp.), dan penggerek batang (Zeuzera sp.). Insektisida yang sering digunakan untuk pemberantasan belalang, ulat jengkal, dan kutu putih antara lain adalah Decis, Cupraycide, Lebaycide, Coesar dan Atabron. Penghisap buah dapat diberantas dengan Lebaycide, Cupraycide dan Decis. Penyakit yang sering ditemukan dalam budidaya kakao, yaitu penyakit jamur upas dan jamur akar. Penyakit tersebut disebabkan oleh jamur Oncobasidium thebromae. Selain itu juga sering dijumpai penyakit busuk buah yang disebabkan oleh Phytoptera sp, menyebabkan pohon mati Depperin (2007).

e. Biaya Usahatani

Menurut Soekartawi (1995), biaya usahatani adalah korbanan yang dicurahkan dalam proses produksi yang semula fisik kemudian diberikan nilai rupiah sehingga biaya-biaya tidak lain adalah korbanan. Biaya usahatani diklasifikasikan menjadi 2 yaitu Biaya tetap (fixed cost) adalah biaya yang dipergunakan tidak habis dalam satu proses produksi dan terus dikeluarkan walaupun produksi yang diperoleh banyak atau sedikit, besar biaya tidak tergantung pada besar kecilnya biaya produksi yang diperoleh. Biaya tetap meliputi: sewa, tanah, pajak, biaya alat pertanian dan penyusutan alat pertanian. Dan biaya Variabel (variable cost) adalah biaya yang besar kecilnya dipengaruhi oleh hasil produksi. Biaya variabel ini meliputi: biaya bibit, biaya pupuk, biaya pengolahan tanah, dan biaya tenaga kerja.

f. Produksi Usahatani

Suatu pengguna faktor produksi dikatakan efisien secara teknis (efisien teknis) kalau faktor produksi yang dipakai menghasilkan produksi maksimal. Usahatani dikatakan efektif bila petani atau produsen dapat mengalokasikan sumberdaya yang mereka miliki sebaik baiknya. Dikatakan efisien bila pemanfaatan sumber daya tersebut menghasilkan keluaran atau output yang melebihi masukan atau input. Pengertian efisien sangat relatif, efisien diartikan sebagai penggunaan input sekecil kecilnya untuk mendapatkan produksi yang sebesar besarnya (Soekartawi, 1995).

Proses produksi memiliki risiko yang relatif tinggi. Dua ciri khas ini muncul karena pertanian melibatkan makhluk hidup dalam satu atau beberapa tahapnya dan memerlukan ruang untuk kegiatan itu serta jangka waktu tertentu dalam proses produksi. Beberapa bentuk pertanian modern (misalnya budidaya alga, hidroponika) telah dapat mengurangkan ciri-ciri ini tetapi sebagian besar usaha pertanian dunia masih tetap demikian. Proses juga diartikan sebagai cara, metode ataupun teknik bagaimana produksi itu dilaksanakan. Produksi adalah kegiatan untuk menciptakan danan menambah keguanaan (utility) suatu barang dan jasa. 
Menurut Ahyari (2002) proses produksi adalah suatu cara, metode ataupun teknik menambah kegunaan suatu barang dan jasa dengan menggunakan faktor produksi yang ada.

Produksi merupakan salah satu kegiatan yang berhubungan erat dengan kegiatan ekonomi. Melalui proses produksi bisa dihasilkan berbagai macam barang yang dibutuhkan oleh manusia. Tingkat produksi juga dijadikan sebagai patokan penilaian atas tingkat kesejahteraan suatu negara. Jadi tidak heran bila setiap negara berlombalomba meningkatkan hasil produksi secara global untuk meningkatkan pendapatan perkapitanya.

Proses produksi atau lebih dikenal budidaya tanaman atau komoditas pertanian merupakan proses usaha bercocok tanam/ budidaya dilahan untuk menghasilkan bahan segar (raw material). Bahan segar tersebut dijadikan bahan baku untuk menghasilkan bahan setengah jadi (work in processs) atau barang jadi (finished product) di industri-industri pertanian atau dikanal dengan nama agroindustri (agrifood industry) (Assauri, 1993).

Buah kakao dapat dipanen apabila terjadi perubahan warna kulit pada buah yang telah matang. Sejak fase pembuahan sampai menjadi buah dan matang, kakao memerlukan waktu sekitar 5 bulan.Buah matang dicirikan oleh perubahan warna kulit buah dan biji yang lepas dari kulit bagian dalam. Bila buah diguncang, biji biasanya berbunyi. Keterlambatan waktu panen akan berakibat pada berkecambah nya biji didalam. Terdapat tiga perubahan warna kulit pada buah kakao yang menjadi kriteria kelas kematangan buah di kebun-kebun yang mengusahakan kakao. Proses diartikan sebagai suatu cara, metode dan teknik bagaimana sesungguhnya sumbersumber (tenaga kerja, mesin, bahan dan dana) yang ada diubah untuk memperoleh suatu hasil. Produksi adalah kegiatan untuk menciptakan atau menambah kegunaan barang atau jasa (Assauri, 1993).

g.Pendapatan Usahatani

Pendapatan hasil bersih dari kegiatan suatu usahatani yang diperoleh dari hasil bruto (kotor) dikurangi biaya yang digunakan dalam proses produksi dan biaya pemasaran (Mubyarto, 1994).

Menurut Soekartawi (1995), bahwa pendapatan dibagi menjadi 2 bagian yaitu pendapatan kotor (penerimaan), adalah nilai produksi total usahatani dalam jangka waktu tertentu baik yang dijual, dikonsumsi oleh rumah tangga petani, dan disimpan dalam gedung pada akhir tahun, dan pendapatan bersih usahatani adalah selisih antara pendapatan kotor dengan biaya produksi seperti upah buruh, pembelian bibit, obatobatan dan pupuk yang digunakan oleh petani. 


\section{PEMBAHASAN}

\section{Macam-macam bisnis pertanian}

Bisnis sektor pertanian Indonesia bisa dibilang cukup beraneka ragam dan menjanjikan sebuah keuntungan. Bagaimana tidak, mayoritas perekonomian masyarakat Indonesia bergerak di sektor pertanian.Sektor pertanian yan g dimaksud tersebut bukan hanya pertanian dalam artian sempit akan tetapi merambah ke pertanian dalam artian luas. Sektor pertanian dalam artian luas tersebut sangat memberi prospek dalam berbisnis. Sektor itu dapat dikelompokkan menjadi:

\section{Bisnis Pertanian Rakyat}

Bisnis pertanian rakyat atau disebut dengan pertanian dalam artian sempit merupakan sektor yang tidak asing lagi di kalangan masyarakat Indonesia. Banyak masyarakat di Indonesia yang menggeluti bisnis sektor ini dari jaman dahulu secara turun temurun hingga saat ini. Dikarenakan turun temurun tersebut, bisnis pertanian rakyat bisa dibilang mempunyai berbagai variasi jenis. Bisnis pertanian rakyat bisa meliputi jenis pertanian pangan, sayuran, buah-buahan, serta tanaman lain yang mempunyai potensi diperjual belikan.

\section{Bisnis Perkebunan}

Bisnis perkebunan merupakan bisnis usaha penanaman lahan dengan berbagai tanaman keras. Ada dua macam perkebunan, yaitu perkebunan rakyat dan perkebunan besar. Perkebunan rakyat adalah perkebunan yang dikelola oleh rakyat. Perkebunan besar biasanya dikelola oleh pemerintah atau perusahaan perkebunan. Perkebunan besar biasanya menanam karet, kelapa, kelapa sawit, dan tebu. Bukan hanya itu, akan tetapi tanaman perkebunan dapat digolongkan ke dalam dua golongan, yaitu tanaman musiman dan tanaman tahunan.

1) Contoh tanaman perkebunan musiman atau berumur pendek adalah tebu, tembakau, dan rosela.

2) Contoh anaman perkebunan tahunan atau berumur panjang atau tahunan adalah teh, kopi, cengkeh, lada, karet, kelapa, dan kelapa sawit.

Hasil perkebunan tersebut kebanyakan lebih ditujukan untuk ekspor sehingga dapat menghasilkan omset yang besar dan sangat menjanjikan. Tak heran jika sektor ini sekarang menjadi incaran para pengusaha konglongmerat di negeri ini.

\section{Bisnis Kehutanan}

Bisnis kehutanan adalah bisnis usaha pengelolaan komoditas hasil hutan seperti kayukayu besar, rotan, damar, kemenyan dan lainya. Dari kesemua hasil tersebut salah satu hasil hutan yang akhir-akhir ini cukup prospek adalah pengolahan kayu jati. Produk pengolahan kayu jati ini cukup laku dipasaran. Pusat pengolahan kayu jati tersebut banyak terdapat di 
Jawa Barat, Jawa Tengah, dan Jawa Timur. Daerah penghasil kayu jati hutan adalah Kalimantan, Sumatera, dan Papua.

\section{Bisnis Peternakan}

Bisnis peternakan adalah bisnis usaha memelihara binatang peliharaan yang dapat diambil manfaatnya sehingga mampu memberikan suatu keuntungan. Usaha bisnis peternakan dapat digolongkan menjadi tiga, yaitu peternakan hewan besar, peternakan hewan kecil, dan peternakan unggas.

1) Contoh peternakan hewan besar adalah peternakan sapi, kerbau, dan kuda. Peternakan hewan besar banyak dilakukan di daerah dengan padang rumput yang luas. Contohnya di Nusa Tenggara Timur.

2) Contoh peternakan hewan kecil adalah peternakan kambing, domba, kelinci, dan babi.

3) Contoh peternakan unggas adalah peternakan ayam, itik, entok, dan burung.

Bisnis peternakan di Indonesia ada yang dikelola secara kecil-kecilan dan ada juga yang dikelola secara besar-besaran. Peternakan kecil-kecilan dilakukan di rumah-rumah penduduk, contohnya peternakan ayam, kambing, kerbau, dan kelinci. Peternakan besarbesaran biasanya dilaksanakan oleh pemerintah dan pengusaha swasta. Kedua sektor usaha peternakan tersebut menghasilkan daging, telur, susu, dan kulit. Komoditas tersebutlah yang biasanya selalu memenuhi permintaan konsumen di pasar dalam skala Nasional.

\section{Bisnis Perikanan}

Sebagaimana kita ketaui, Indonesia mempunyai wilayah perairan yang sangat luas. Hal tersebut dikarenakan Indonesia merupakan Negara kepulauan yang terdiri lebih dari tujuh belas ribu pulau. Dari sisi itulah Indonesia bisa dibilang mempunyai potensi bisnis usaha perikanan yang menjanjikan.

Bisnis usaha perikanan di Indonesia dibedakan menjadi dua, yaitu perikanan darat dan perikanan laut.

1) Perikanan darat adalah usaha memelihara dan menangkap ikan di perairan darat. Perikanan darat meliputi perikanan air tawar dan perikanan air payau.

a) Perikanan air tawar diusahakan di sungai, danau, rawa, waduk, atau bendungan di lembah-lembah sungai dan empang, serta sawah yang digenangi air selama tanaman padi masih muda.

b) Perikanan air payau diusahakan di tambak-tambak yang terdapat di tepi pantai.

2) Perikanan air laut adalah usaha menangkap ikan di pantai atau di laut dan pembudidayaan ikan laut dalam tambak-tambak. Di Indonesia, usaha penangkapan ikan laut banyak dilakukan oleh nelayan tradisional. Lahan perikanan air laut di Indonesia sangat luas. 
Pada musim ikan hasil tangkapan para nelayan akan berlimpah ruah sehingga harga di pelelangan ikan akan merosot. Selain ikan, laut juga menghasilkan mutiara, udang, rumput laut, dan garam. Hasil-hasil itu digunakanuntuk memenuhi keperluan penduduk dan sebagai bahan ekspor. Ekspor hasil laut Indonesia yangterkenal adalah udang. Produksi udang dilakukan dengan membuat tambak udang.

Uraian mengenai macam-macam bisnis pertanian diatas sepertinya selaras terhadap yang dikatakan oleh (Mubyarto, 1986:21) bahwa pertanian terbagi ke dalam pertanian dalam arti luas dan pertanian dalam arti sempit, yang mana keduanya mempunyai potensi bisnis pertanian yang bagus. Bisnis sektor pertanian yang dimaksud mencangkup:

1) Pertanian rakyat (disebut juga sebagai pertanian dalam arti sempit).

2) Perkebunan (termasuk didalamnya perkebunan rakyat atau perkebunan besar).

3) Kehutanan.

4) Peternakan.

5) Perikanan (dalam perikanan dikenal pembagian lebih lanjut yaitu perikanan darat dan perikanan laut).

\section{Potensi bisnis pertanian di Indonesia}

Indonesia merupakan negara kepulauan dengan kurang lebih 17.508 pulau yang tersebar di 33 provinsi. Hal tersebut menjadikan Indonesia memiliki potensi alam yang sangat melimpah akan keanekaragaman flora dan faunanya. Selain itu Indonesia juga dikenal sebagai negara agraris. Sebagai Negara agraris, Indonesia memiliki tanah yang subur dan dapat dimanfaatkan untuk berbagai jenis tanaman pertanian. Banyak sekali jenis tanaman yang bisa ditanam di Indonesia seperti sayur - mayur, tanaman obat-obatan, tanaman pangan seperti padi-padian, umbi -umbian hingga pertanian kayu - kayu berkualitas tinggi dan bernilai jual mahal.

\section{Potensi Keanekaragaman Hayati}

Indonesia memiliki potensi sumberdaya alam, termasuk plasma nutfah, yang melimpah. Bio-diversity darat Indonesia merupakan terbesar nomor dua di dunia setelah Brasil, sedangkan bila termasuk biodiversity laut maka Indonesia merupakan terbesar nomor satu di dunia. Hal ini dapat dilihat dengan beragamnya jenis komoditas pertanian tanaman pangan, hortikultura, perkebunan dan peternakan yang sudah sejak lama diusahakan sebagai sumber pangan dan pendapatan masyarakat.

Aneka ragam dan besarnya jumlah plasma nutfah tanaman dan hewan menjadikan Indonesia mempunyai potensi bisnis yang prospek. Dari hasil keranekaragam tersebut bermunculan bahan olahan yang dapat digunakan dalam proses bahan baku industri. Banyak 
orang-orang yang memanfaatkan potensi tersebut dengan mencoba mendirikan industri rumah tangga. Atas adanya industri rumah tangga tersebut, para angkatan kerja banyak yang terserap, dan mampu meningkatkan perekonomian masyarakat.

\section{Potensi Lahan}

Ada banyak potensi lahan di Indonesia yang bisa digunakan dan bisa digarap petani Indonesia. Jika kesemuanya itu bisa dimanfaatkan dengan baik, maka akan menjadi sebuah peluang bisnis yang menguntungkan. Banyak potensi yang dimiliki Indonesia yang bisa mejadi peluang bisnis karena Indonesia itu adalah negara yang kaya akan sumber daya alam dan memiliki tanah yang subur. Oleh karena itu kita harus bisa memafaatkan kekayaan Indonesia dengan baik dan benar sehingga menjadi peluang bisnis yang menguntungkan.

Indonesia memiliki potensi ketersediaan lahan yang cukup besar dan belum dimanfaatkan secara optimal. Data dari kajian akademis yang dilaksanakan oleh Direktorat Jenderal Pengelolaan Lahan dan Air, Kementerian Pertanian pada tahun 2006 memperlihatkan bahwa total luas daratan Indonesia adalah sebesar 192 juta ha, terbagi atas 123 juta ha (64,6 persen) merupakan kawasan budidaya dan 67 juta ha sisanya $(35,4$ persen) merupakan kawasan lindung. Dari total luas kawasan budidaya, yang berpotensi untuk areal pertanian seluas 101 juta ha, meliputi lahan basah seluas 25,6 juta ha, lahan kering tanaman semusim 25,3 juta ha dan lahan kering tanaman tahunan 50,9 juta ha. Sampai saat ini, dari areal yang berpotensi untuk pertanian tersebut, yang sudah dibudidayakan menjadi areal pertanian sebesar 47 juta ha, sehingga masih tersisa 54 juta ha yang berpotensi untuk perluasan areal pertanian,

\section{Potensi Perairan}

Selain dikenal sebagai Negara agraris, Indonesia juga mempunyai potensi sebagai Negara maritim. Hal itu tidak lepas dalam kaitanya wilayah Indonesia yang sebagian besar adalah wilayah perairan dan lautan. Tentu saja keadaan tersebut dapat menjadikan peluang tersendiri dalam pengembangaan usaha perikanan. Dari sisi tersebutlah yang menjadikan potensi bisnis perikanan di Indonesia mempunyai prospek yang bagus dalam persaingan dunia kerja.

Sektor perikanan merupakan sektor yang cukup baik dalam peningkatan pendapatan nasional. Banyak pasar ekspor yang akhir-akhir ini tertarik terhadap hasil perikanan Indonesia. Sebut saja Negara-negara di timur tengah dan Amerika yang memberi peluang masuknya produk perikanan Indonesia. Alhasil pendapatan nasional cukup meningkat akibat sumbangan ekspor perikanan ke Negara luar negeri. 
Besar pendapatan sektor pertanian (Pertanian, Peternakan, Kehutanan \& Perikanan) menunjukkan angka yang terus meningkat dari tahun 2004 hingga 2009, yaitu sebesar Rp 329.124,6 Miliar pada tahun 2004 yang terus meningkat di tahun-tahun berikutnya hingga mencapai Rp 858.252 Miliar pada tahun 2009. Begitu pula dengan pendapatan sektor industri yang juga mengalami peningkatan, besar pendapatan sektor industri (industri pengolahan) menunjukkan angka yang terus meningkat dari tahun 2004 hingga 2009, yaitu sebesar Rp 644.342,6 Miliar pada tahun 2004 yang terus meningkat di tahun-tahun berikutnya hingga mencapai Rp 1.480.905,4 Miliar pada tahun 2009. Pendapatan Dometik Bruto (PDB) Indonesia pun secara keseluruhan mengalami peningkatan, besar PDB tahun 2004 adalah Rp 2.295.826,2 Miliar dan meningkat pada tahun berikutnya menjadi Rp 2.774.281,1 Miliar, kemudian meningkat lagi pada tahun 2006 menjadi Rp 3.339.216,8 Miliar kemudian meningkat lagi pada tahun 2007 menjadi Rp 3.950.893,2 Miliar, pada tahun 2008 menjadi Rp 4.951.356,7 Miliar dan meningkat lagi pada tahun 2009 menjadi Rp 5.613.441,7 Miliar, angka yang cukup signifikan dalam perekonomian suatu Negara.

Silitonga, $d k k, 1994 ; 53$ mengatakan bahwa pertanian merupakan sektor terbesar dari hampir setiap sektor perekonomian negara berkembang termasuk negara Indonesia. Sektor ini menyediakan pendapatan bagi hampir seluruh angkatan kerja yang ada, menghasilkan bahan mentah, bahan baku atau penolong bagi industri dan menjadi sumber terbesar penerimaan devisa dalam peningkatan perekonomian Negara.

\section{KESIMPULAN}

Dari berbagai uraian di atas dapat kita tarik kesimpulan bahwa macam-macam bisnis pertanian di Indonesia meliputi: bisnispertanian rakyat (disebut juga sebagai pertanian dalam arti sempit), bisnis perkebunan (termasuk didalamnya perkebunan rakyat atau perkebunan besar), bisnis kehutanan, bisnis peternakan, dan bisnis perikanan (dalam perikanan dikenal pembagian lebih lanjut yaitu perikanan darat dan perikanan laut).

Potensi bisnis pertanian terhadap perekonomian Indonesia dapat dilihat dari potensi keanekaragaman hayati yang begitu banyak dan tersebar di berbagai daerah di Indonesia. Potensi perikanan yang melimpah karena kondisi Indonesia adalah Negara kepulauan. Selain itu Indonesia juga mempunyai potensi lahan yang luas dan mampu menyerap tenaga kerja dalam peningkatan perekonomian masyarakat sehingga mampu berkontribusi dalam peningkatan pendapatan nasional. 


\section{REFERENCES}

Abd. Rahim dan Diah Retno Dwi Hastuti 2007, Ekonomika Pertanian, Pengantar Teori dan Kasus, Penebar Swadaya.

Assauri, Sofjan, (1999), Manajemen Produksi dan Operasi. Edisi Empat, Lembaga Penerbit Fakultas Ekonomi Universitas Indonesia, Jakarta.

Assauri, Sofjan, (1993), Manajemen Produksi. Edisi Ketiga, Lembaga Penerbit Fakultas Ekonomi Universitas Indonesia, Jakarta.

Mubyarto. 1986. Pengantar Ekonomi Pertanian.Jakarta: LP3ES.

Ali, M. (2015). PENGARUH DOSIS PEMUPUKAN NPK TERHADAP PRODUKSI DAN KANDUNGAN CAPSAICIN PADA BUAH TANAMAN CABE RAWIT (Capsicum frutescens L.). JURNAL AGROSAINS: KARYA KREATIF DAN INOVATIF, 2(2), 171178.

LASTIANTI, S. D. D. (2015). KAJIAN MANAJEMEN RISIKO SEBAGAI UPAYA UNTUK MENCAPAI KEBERHASILAN PADA PROYEK KONSTRUKSI BAJA DAN SIPIL DI PT SUPRA SURYA INDONESIA. UNIVERSITAS AIRLANGGA.

Lestari, V. N. S. (2017). PENTINGNYA MOTIVASI DALAM UPAYA MENINGKATKAN PRODUKTIVITAS KARYAWAN.

Roesli, M., Heri, A., \& Rahayu, S. (2017). Authority of Land Procurement Committee In The Implementation of Compensation For Land Acquisition. YURISDIKSI: Jurnal Wacana Hukum Dan Sains, 10(2), 46-59.

Silitonga, dkk. 1994. Perkembangan Ekonomi Pertanian Indonesia 1964-1994.Jakarta:

Soekartawi, 1995, Analisis Usaha Tani, UI-Press, Jakarta.

Suratiyah. 2006. Ilmu Usahatani. Penebar Swadaya. Jakarta. 